\title{
Knowledge, attitudes, and practices in reproductive and sexual health
}

\author{
Valle de los Chillos, Rumiñahui County, Province of Pichincha, \\ Ecuador
}

\author{
Jessica Beckwith*
}

\begin{abstract}
To help support and direct the Lions Club's construction of a Community Health Clinic specializing in Reproductive and Sexual Health, this descriptive study began in November of 2004 and was completed in May 2005. The sample consists of 552 high school students in Rumiñahui County, and surveys were used to study four principle themes: reproductive and sexual health education, family planning, sexually transmitted infections, and domestic violence. The results show a widespread lack of accurate and adequate information about reproductive and sexual health. Statistically significant variables studied include sex, age, monthly income, and age of first sexual experience. Female sex, younger age, lower monthly income, and younger age of first sexual experience all contribute to a lower quality of reproductive and sexual health, in terms of having less information about and access to these four aspects of reproductive and sexual health.
\end{abstract}

KEYWORDS: Reproductive and sexual health; Valle de los Chillos; Ecuador; sexual education; family planning; sexually transmitted infections; domestic violence

\section{INTRODUCTION}

Ecuadorians, in general, lack access to adequate information about and care for reproductive and sexual health (RSH) issues. Many authors $(1,2)$ and organizations, including the World Health Organization and United Nations Population Fund confirm this fact (3). For instance, the infant mortality rate for the year 2000 was 45.6 per 1,000 live births (3); the percentage of births attended by health professionals, in the year 2001 , was $72.6 \%$ (4); and the maternal mortality rate in 2001 dropped to 97 deaths per 100,000 live births (4).

In comparison, most developed countries have both

* To whom correspondence should be addressed: Jessica Beckwish, Rotary Ambassadorial Scholar, Pontificia Universidad Católica del Ecuador, contact author for original version in Spanish 3220 Girard Ave S \#305, Minneapolis, MN 55408 beckwith_jessica@yahoo.com infant and maternal mortality rates under 10 deaths per 1,000 and 100,000 births, respectively. Among adolescents, $66 \%$ of male students possess basic knowledge about RSH, while only $40 \%$ of female students do (1); $57 \%$ of 10-17 year olds have misinformation about the transmission of HIV and $31 \%$ do not know how to prevent it (2); and $33 \%$ of adolescent boys and $57 \%$ of adolescent girls who have engaged in premarital sex were forced to have their first sexual relationship (1).

In order to improve this situation in a satellite community of Quito, the Lions Club of the Valle de los Chillos acquired funding to build a Community Health Clinic specializing in reproductive and sexual health (RSH). This study defines the RSH situation in this area, focusing on: reproductive and sexual health education, family planning, sexually transmitted 
infections, and domestic violence.

\section{METHODS}

Universe and sample populations

The universe consists of high school students in fifth and sixth years (equivalent to juniors and seniors in American high schools) at the 15 high schools functioning in Rumiñahui County in the year 2002 (5). Of the 15 high schools in the county, the following seven were randomly chosen to be included in the sample: Giovanni Antonio Farina, Centro Educativo Integral, Colegio Nacional Mixto San Rafael, Unidad Educativa Católica Santa Ana, Unidad Educativa Darío Figueroa, Colegio Nacional Juan de Salinas, and Colegio Nacional Técnico Jacinto Jijón y Caamaño. Their participation depended on permission from the school administrators and teachers. The sample includes three public schools (italicized) and four private, but does not include any night schools. The public schools are considered "large" for the sake of this study, with over 80 students per grade level. All private schools were considered "small", with class sizes ranging from 20 to 80 students.

Five hundred and fifty-two surveys were completed by fifth and sixth year students, with a maximum of 100 surveys in large schools. In the small schools, all fifth and sixth year students who were present on the day of the study were surveyed. The number of students surveyed ranged from 21 at Santa Ana to 100 at Juan de Salinas and Jacinto Jijón y Caamaño.

\section{Methods and data collection}

The data collection consisted of a 34-question survey that lasted approximately 15 minutes. The survey focused on the four themes described earlier in this paper and determined which topics students were further interested in. All answers were exclusive (choose one and only one), with very few students choosing more than one answer. Students were surveyed during classes, with the permission of the teachers and school administrators.

To ensure the reliability of the data collection methods, all surveys were performed by the author in similar conditions. The survey was designed in Spanish by the author, with input from José Terán, pediatrician and Professor of Medicine at the Universidad Católica del Ecuador. For the purpose of receiving further input, the author translated the survey to English and received feedback from Steve Hirsch, Clinical Professor in the Department of Education Leadership and Counseling Psychology; and Anne Hirsch, Associate Dean for Academic Affairs of the Nursing School, both at Washington State University.

\section{Execution}

The pilot study, conducted in November of 2004, tested the effectiveness of the instruments and helped identify necessary changes. Finalized surveys were completed in March, April, and May of 2005. The principle difficulty encountered by the author during data collection was the inability to take a completely random sample of the population, due to the necessity of obtaining authorization from high school administrators and teachers. Only administrators sympathetic to the idea of this study permitted the surveys and interviews to be done. Furthermore, given that students were surveyed while in class, and that some classes were taking tests or were out of the classroom, not all eligible students were surveyed.

The biostatistics program EPI-INFO, from the Centers for Disease Control, was utilized in the processing and analysis of data. The statistical tests used to determine significance were Chi squared with the Yates correction or the Fischer exact test, when necessary. All subjects were free to refuse to participate in the study, though no student declined to complete a survey. Each phase of the study was completed with the utmost confidentiality; participants were never asked to provide identifying information.

\section{RESULTS}

\section{Demographic information}

Of the 552 students surveyed, 237 (42.9\%) are female and $315(57.1 \%)$ are male. Their average age is 16.86 years, the median and mode is 17 years. See Illustration 1 for details:

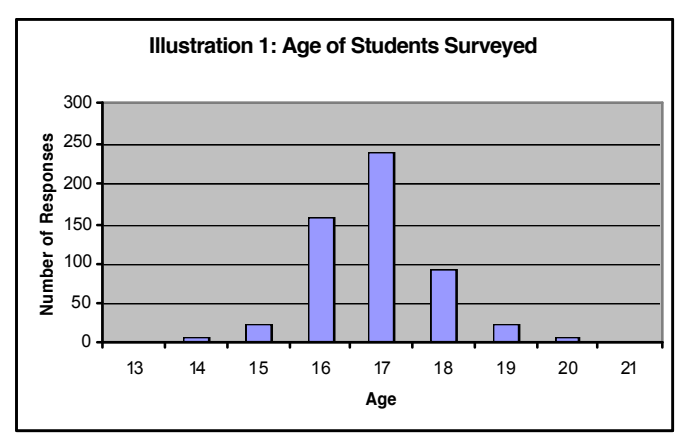

As a measure of income, cutoff points of $\$ 500$ and $\$ 1,000$ (USD) were based on Ecuador's average income of $\$ 250$ per person in urban areas, for the year 2002 (6). A household of two earners at the average income would yield a household income of $\$ 500$, this study's maximum cutoff for "low" income. More than double this amount $(\$ 1,000)$ was considered "high" income. Over a third of the students did not know the monthly income of their families. Of those who did, most were considered low income, followed by middle and then 
high income families (see Illustration 2).

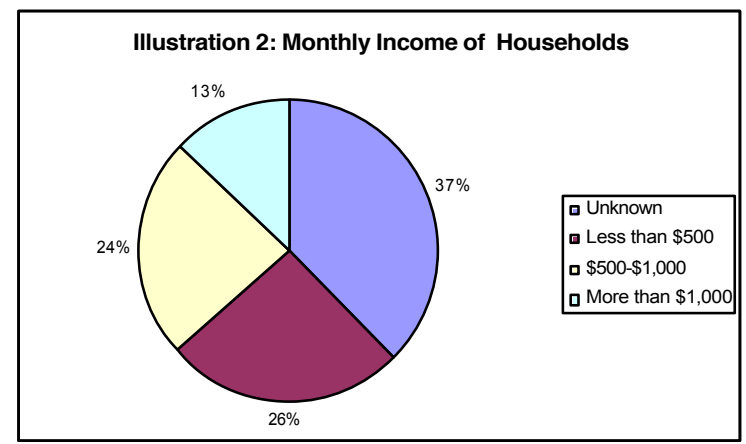

The majority of these families have four or five people living in the household, with the number of inhabitants ranging from 2 to 13 and averaging 5.04. At the extremes, $9.1 \%$ of the students live in a house with three or fewer people and $27.6 \%$ live in a household with six or more.

The vast majority $(98.2 \%)$ of the students are single, while the other $1.8 \%$ live in "free union", defined as living together but unmarried. Two hundred five $(37.1 \%)$ students were in an intimate relationship at the time of the study: $38 \%$ of female students and $36.5 \%$ of male students. Thirteen students $(2.4 \%)$, eight male and five female, have children.

\section{Education/information about reproductive and sexual health}

The majority of students $(60.51 \%)$ believe that parents and high schools share the responsibility for their education in reproductive and sexual health matters. The complete answers can be seen in Table 1 .

Table 1. Who should be responsible for educating children?

\begin{tabular}{lcc}
\hline & Number of Responses & Percentage \\
\hline Friends & 2 & $0.36 \%$ \\
\hline High School & 3 & $0.54 \%$ \\
\hline No one & 2 & $0.36 \%$ \\
\hline Unknown & 1 & $0.18 \%$ \\
\hline Parents & 65 & $11.78 \%$ \\
\hline Parents and High School & 334 & $60.51 \%$ \\
\hline Health Professionals & 79 & $14.31 \%$ \\
\hline Everyone & 66 & $11.96 \%$ \\
\hline Total & 552 & $100.00 \%$ \\
\hline
\end{tabular}

Despite the fact that 334 students believe that parents and high schools should be responsible for $\mathrm{RSH}$ education, only 274 actually receive $\mathrm{RSH}$ information from these sources (see Table 2), a difference of $10.9 \%$. Similarly, $14.3 \%$ of students believe that health professionals should be responsible for educating them, while only $5.1 \%$ of students actually receive information from this source. In contrast, a greater proportion of students receive $\mathrm{RSH}$ information from friends and the media than those who believe this source should be responsible for $\mathrm{RSH}$ education. Table 2 describes where students receive general information about RSH, as well as information specifically about family planning. Note that only 268 students $(48.6 \%)$ responded that they have received information about family planning.

Family is a crucial factor in students' level of knowledge about RSH; 336 students, or $60.9 \%$, responded that they converse with their parents about $\mathrm{RSH}$. Monthly income is a statistically significant factor $(\mathrm{P}<0.05)$ for determining whether or not families talk about RSH; families with high levels of income are more likely to converse with their children about RSH than families with low levels of income. Illustration 3 details the reasons why $39.1 \%$ of students and families do not talk about RSH.

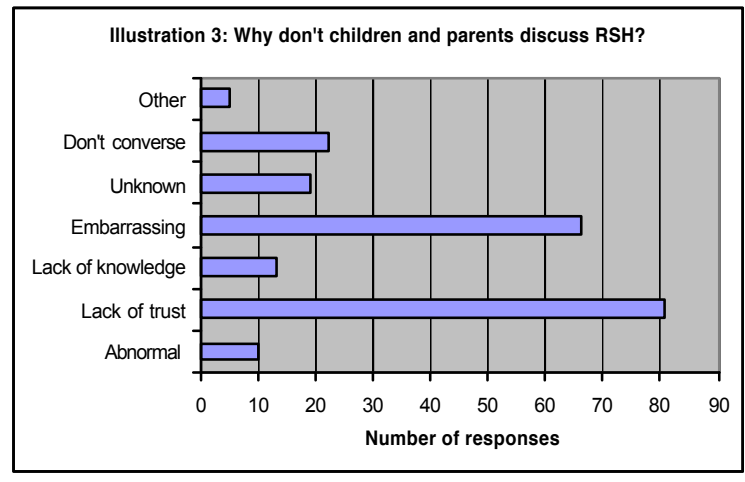

Family planning

The majority of the students surveyed $(59.3 \%)$ have not had their first sexual experience, as defined by each student. Of those who have $(40.7 \%)$, the average age of their first experience is 14.58 years, see Illustration 4 for details.

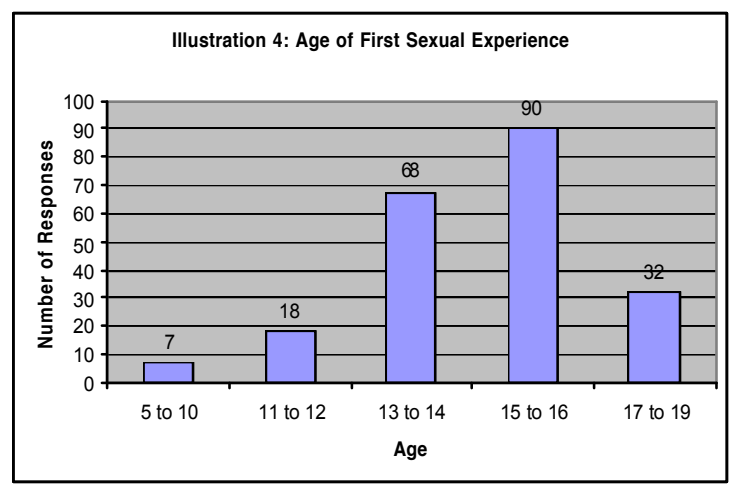


Gender is a statistically significant factor $(\mathrm{P}<0.05)$ for predicting the age of first sexual experience; female students are more likely than male students to wait to have their first sexual experience.

When asked their "ideal number of children", the average response was 2.06 children, with a minimum of zero, a maximum of 15, a median and mode of two. Slightly over half of the students wanted two children, while nearly a quarter wanted three.

Five hundred thirty-five students $(96.9 \%)$ responded that they knew of some method of birth control. A slightly lower number, 448 students $(81.5 \%)$ responded that they use, had used, or would use some method of contraceptives. Gender is a statistically significant factor in the decision to use birth control. Female students were less likely to use contraceptives than male students $(\mathrm{P}<0.05)$, citing reasons such as fear of side effects and the desire to have children. Nearly half of those who responded that they would not use birth control justified that response with a fear of side effects. Forty percent of respondents did not know why they would not use contraceptives and slightly over $10 \%$ said they would not use birth control because they wanted to have children.

Of students who have used, do use, or would use birth control, the condom is the preferred method, followed by the rhythm method, withdrawal, and oral contraceptives. Illustration 5 details the results.

\section{Sexually transmitted infections}

Only 62 students $(11.2 \%)$ had undergone a physical exam to diagnose sexually transmitted infections (STIs), with gender and age of first sexual experience being statistically significant factors for having

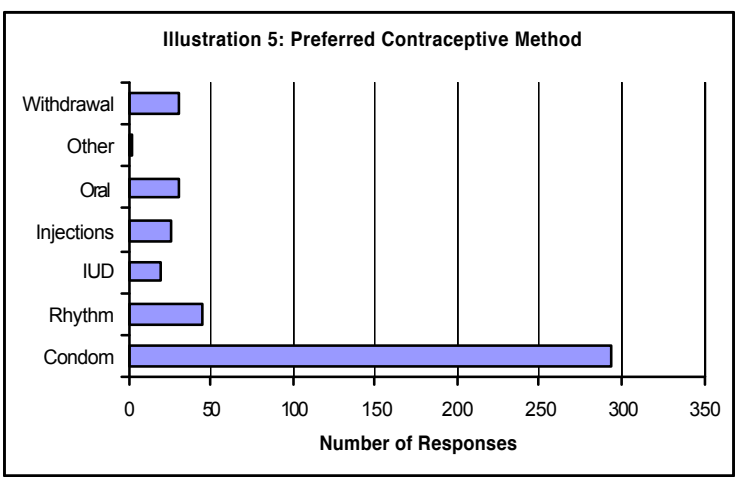

undergone an exam. Male students and sexually active students were more likely than female students or nonsexually active students to have had a physical exam to diagnose STIs $(\mathrm{P}<0.05$ in both cases). Only $17.8 \%$ of sexually active students had undergone this type of physical exam.

Nearly all students $(97.8 \%)$ had heard of some STI. Age is a statistically significant factor $(\mathrm{P}<0.05$, using the Fisher exact test) for predicting if students had heard of any STI. Students older than 17 years of age were more likely to have heard of a STI, compared to students younger than 17 . Though most students had heard of a STI, many did not know how to prevent them or how they are passed from one person to another. Table 3 details responses to the question, "How can you contract a STI without having sex?"

Nearly $10 \%$ of students responded that oral contraceptives provide protection from STIs and HIV/AIDS. Nearly one quarter $(24.8 \%)$ believe that HIV/AIDS can be passed through everyday contact with the saliva or sweat of an infected person.

Table 2. Where do you receive information about RSH?

\begin{tabular}{lcccc}
\hline & General RSH Information & Percentage of Total & Family Planning Information & Percentage of Total \\
\hline Friends & 13 & $2.36 \%$ & 4 & $1.49 \%$ \\
\hline High School & 78 & $14.13 \%$ & 62 & $23.13 \%$ \\
\hline Church & 4 & $0.72 \%$ & 9 & $3.36 \%$ \\
\hline Media & 83 & $15.04 \%$ & 33 & $12.31 \%$ \\
\hline None & 7 & $1.27 \%$ & N/A \\
\hline Other & 3 & $0.54 \%$ & 2 & $0.75 \%$ \\
\hline Parents & 62 & $11.23 \%$ & 47 & $17.54 \%$ \\
\hline Parents and High School & 274 & $49.64 \%$ & 77 & $28.73 \%$ \\
\hline Health Professionals & 28 & $5.07 \%$ & 34 & $12.69 \%$ \\
\hline Total & 552 & $100.00 \%$ & 268 & $100.00 \%$ \\
\hline
\end{tabular}


Table 3. How can you contract STIs without having sex?

\begin{tabular}{lcc}
\hline & Number of Responses & Percentage \\
\hline Kisses/Handshakes & 25 & $4.53 \%$ \\
\hline Intimate Physical Contact & 90 & $16.30 \%$ \\
\hline Contact with Infected Objects & 52 & $9.42 \%$ \\
\hline Syringes/Injections & 250 & $45.29 \%$ \\
\hline Unknown & 14 & $2.54 \%$ \\
\hline Other & 3 & $0.54 \%$ \\
\hline Blood & 118 & $21.38 \%$ \\
\hline Total & 552 & $100.00 \%$ \\
\hline
\end{tabular}

Exactly half of the students responded that they knew how to correctly use a condom, and nearly half (49.8\%) responded that they would be embarrassed to buy a condom, while $23.4 \%$ would be embarrassed to use one. Gender and sexual experience are statistically significant factors $(\mathrm{P}<0.05)$ for feeling embarrassed to buy a condom. Female students and those who had not yet had their first sexual experience were more likely to be embarrassed to buy and/or use a condom than male students or those who had had their first sexual experience.

\section{Domestic violence}

During the month prior to the study, physical or verbal aggression occurred in $20.8 \%$ of students' homes. Adolescents who have witnessed domestic violence are more likely to be involved in a violent relationship in the future, as are those involved in a relationship with an unequal distribution of power. Two questions asked students in an intimate relationship who was responsible for making decisions about physical intimacy and family planning. The majority responded that neither partner makes these decisions.

Another interesting component of this power dynamic in a relationship is the likelihood of young people to say no to a partner requesting sex. In this study, $23.4 \%$ of students believe that it is not okay to refuse to sex under any circumstance, $27.6 \%$ believe

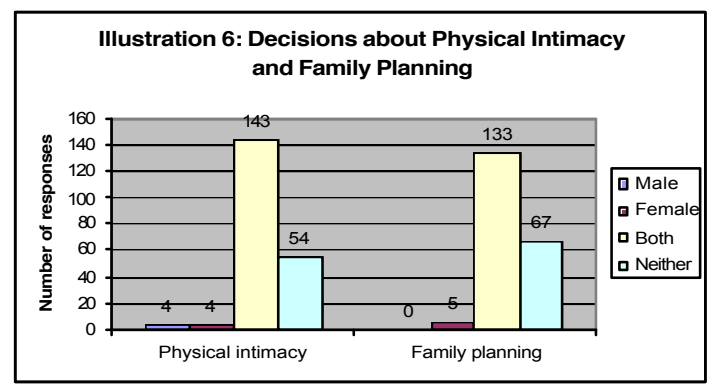

that it is okay at any time, and the other $49.0 \%$ believe that it depends on the situation.

\section{DISCUSSION}

The results of this study confirm data found in other studies, primarily that "sexuality and fertility are some of the severest taboos" (3) and that "adolescents lack sources of reproductive and sexual health education. Also, mothers and fathers do not respond to their adolescents' questions about sexuality because of embarrassment and a lack of knowledge" (3). The findings that most specifically support these statements are that:

- under half of students responded that they had received information about family planning,

- approximately $40 \%$ of students do not converse with their parents about RSH,

- half of students said they would be embarrassed to purchase a condom, and

- approximately two-thirds of students in a relationship respond that neither they, nor their partners, make decisions regarding physical intimacy or family planning.

This last point is particularly important because open conversation, along with accurate information, is critical to enjoying healthy and safe relationships.

Female students, more than male students, seem to bear the burden of this lack of information and access to quality RSH. For instance, the fact that the majority of students with children are male is because pregnant students lack the support from administrators and teachers necessary to stay in school. Strong social taboos also dictate that pregnant adolescents drop out of school in order to raise the child. Further, females tend to be the victims of both sexual abuse and domestic violence. Though sexual abuse was not directly studied, the young ages at which some students had their first sexual experience (ages 5 to 12, for instance) suggest that these relationships may not have been consensual. The levels of domestic violence cited by the students are most likely underestimates of reality, as aggression or violence may have occurred without the student's realization, or in the month before the study.

It is difficult to compare this study's findings to similar quantitative data because very few studies have focused on the RSH of adolescents in Ecuador. In comparison with the studies of Francisco Sevilla and Nelson Oviedo Valdivieso, the students in this study tend to have a higher level of knowledge about RSH issues, particularly family planning and STIs. Perhaps this can be explained with a difference of one to two years between the studies, but it seems more probable that results differed because of a difference in sample diversity. These authors studied the entire country, while this study focused on the relatively small 
geographic area of Valle de los Chillos.

The author would like to note that in the original study, a number of students, as well as high school teachers from these schools and market vendors from the same area participated in in-depth interviews about the same four RSH variables addressed in the surveys. The results of these interviews are not included in this paper, due to sampling concerns and space constraints, but did add richness and understanding to the study that cannot be conveyed through strictly quantitative methods. Though addressing these topics through qualitative methods is difficult due to the intensity of the social taboos surrounding $\mathrm{RSH}$, future research could involve focus groups, interviews, or ethnographies, in order to paint a more nuanced picture of the RSH challenges facing this population.

\section{CONCLUSION}

This study makes it clear that adolescents in the Valle de los Chillos, Ecuador, suffer from a poor quality of reproductive and sexual health, measured in terms of RSH education and information about RSH, family planning, sexually transmitted infections, and domestic violence. Despite the efforts of many organizations and individuals, misunderstandings about RSH persist and, coupled with inadequate support systems for these students, negatively impact their quality of life. The solution with the greatest potential to impact the concern of poor RSH is also the most complicated: to minimize the social taboos surrounding RSH and open avenues of communication to enable students to obtain necessary information.

Education programs that address RSH should not only involve adolescents, but also must be directed towards the parents and teachers, who often lack accurate information. Parents and teachers should also be taught various ways to approach the topic and stimulate fruitful discussion. Because we have seen that females often bear the greatest burden due to a lack of understanding about $\mathrm{RSH}$, programs designed to address the RSH in this population must be aware of and prepared to address this disparity. For instance, supportive and educational services should be provided to pregnant adolescents, their families, and their schools, in order to enable these women to continue their education. Further, a community center must also provide educational and psychological services for teen victims of sexual abuse and/or domestic violence.

Though this study found a number of areas in which the students lack accurate information, and any presentation of basic information about family planning methods, sexually transmitted infections, and domestic violence would be an improvement on the current level of knowledge, the following three recommendations address the most pressing areas of concern:

1. Present information about family planning methods that do not have significant side effects. For those methods that do cause side effects, provide statistics about the number of users that experience these side effects, as well as the severity of these reactions.

2. Clarify how sexually transmitted infections can be prevented and how they are passed between people. Describe symptoms of common STIs and emphasize that all sexually active students should receive exams to check for STIs, regardless of the presence of symptoms.

3. Promote self respect and respect between partners to enable more open discussion about RSH issues within the context of an intimate relationship. Stress the importance of discussing issues related to physical intimacy and family planning.

Addressing these topics through consistent, open communication between students, teachers, and families will be the most effective method of addressing the poor quality of RSH in this population.

\section{ACKNOWLEDGEMENTS}

Thank you to the many people who helped and supported me in this project, above all the Terán family, who served as my advisors and editors throughout the study. Thank you also to the Rotary Foundation, who funded my year in Ecuador; the Rotary Club Quito Occidente and the Lions Club of Valle de los Chillos for supporting this work; and to Pablo Silva, Jack Mutti, Felipe Bautista, and Anne and Steve Hirsch for their comments. Thank you also to the high school administrators who allowed me in to their schools and to the students who participated in this study.

\section{REFERENCES}

1. Sevilla, Francisco. March. Aportes al marco teórico de la educación y salud sexual y reproductiva. Correo Poblacional: Salud Reproductiva y Gerencia en Salud 2003; 11(1): 16-18.

2. Oviedo Valdivieso, Nelson y Ordóñez Sotomayor, José. Situación de los Adolescentes y jóvenes en el Ecuador. Quito: Centro de Estudios de Población y Desarrollo Social 2003: 17.

3. World Health Organization. WHO Home Page. www.who.org Accessed Feb2004.

4. Instituto Ecuatoriano de Seguridad Social (IESS). IESS Home Page. www.iess.gov.ec. Accessed Feb 2004.

5. Gobierno del Cantón Rumiñahui. Plan estratégico participativo del cantón Rumiñahui: 2002-2022. Quito: Consejo Municipal del Cantón Rumiñahui 2002; May: 59, 93.

6. Instituto Nacional de Estadística y Censo (INEC), Ecuador. INEC Home Page. www.inec.gov.ec. Accessed Feb 2004.

7. United Nations Population Fund. Country Overview: Ecuador. http://www.unfpa.org/profile/ecuador.cfm. Accessed May 2005.

8. Ambrossi, Rodrigo Tenorio. La Intimidad Desnuda: Sexualidad, Cultura Indígena y Salud Reproductiva. Quito: Pan-American Health Organization/World Health Organization 1996 March.

9. Ashford, Laurie. New Population Policies: Advancing Women's Health \& Rights. Population Bulletin, Population Reference 
Bureau 2001 March; 56: 3-42.

10. Bacarreza Schulze, Johnny Carlos. Espacios de debate y diálogo con y para población adolescente en el marco del Programa de Salud Sexual y Reproductiva [Thesis]. Quito: Pontificia Universidad Católica del Ecuador, School of Medicine; 2002.

11. Barros, Teodoro; Barreto, Dimitri; Pérez, Freddy; Santander, Rocío; Yépez, Eduardo; Abad-Franch, Fernando et al. Un modelo de prevención primaria de las enfermedades de transmisión sexual y del VIH/SIDA en adolescentes. Revista Panamericana de la Salud Pública 2001; 10(2).

12. Bertrand, Jane T; Bull, Sheana E.; Glavez, Roberto Santiso; Rosen, James E.; Terbough, Anne Terceros. Family Planning Among Indigenous Populations in Latin America. International Family Planning Perspectives 1995 Dec; 21: 145+.

13. Blum, Agustín Cuesta. El involucramiento del varón bajo una perspectiva de género en los servicios de APROFE. Correo Poblacional: Salud Reproductiva y Gerencia en Salud 2003 March; 11(1).

14. Camacho Soria, María Marisol. Salud reproductiva en mujeres adolescentes jefes de hogar: investigación realizada en Fundación Tierra Nueva [Thesis]. Quito: Pontificia Universidad Católica del Ecuador, School of Social Work; 2001.

15. Center for Reproductive Law and Policy (CRLP). Women of the World - Laws and Policies Affecting their Reproductive Lives Latin America and the Caribbean. CRLP 1997: 38-42.

16. CIA World Factbook. Ecuador Page. http://www.cia.gov/cia/publications/factbook/. Accessed April 2004.

17. Country Report on Human Rights Practices - 2000: Ecuador. United States Government, 2001 Feb.

18. Donaldson, Loraine. Fertility Transition: The Social Dynamics of Population Change. Cornwall, England: TJ Press; 1991.

19. Escobar Koziel, Luis Fernando. Investigación Científica para Médicos. Quito: Pontificia Universidad Católica del Ecuador, School of Medicine; 1999 Sept.

20. Family Health International. Women's Voices, Women's Lives The Impact of Family Planning. Family Health International; 1998.

21. Goicolea, Isabel. Exploring women's needs in an Amazon region of Ecuador. Reproductive Health Matters 2001 May; 9: 193+.

22. Hilfinger Messias, Deanne; Im, Eun-Ok; Page, Aroha; Regev, Hanna; Spiers, Judith; Yoder, Laurie; et al. Defining and Redefining Work: Implications for Women's Health. Gender and Society 1997 June; $11:$ 296-323.

23. Hungría, Miriam Becerra. Mujer y VIH/SIDA. Correo Poblacional: Salud Reproductiva y Gerencia en Salud 2003 June; 11(2).

24. International Planned Parenthood Federation. IPPF Home Page. www.ippf.org. Accessed April 2004.

25. Macintyre, Kate; Bilsborrow, Richard E.; Olmedo, Caton; y Carrasco, Rodolfo. Rapid surveys for program evaluation: design and implementation of an experiment in Ecuador. Revista Panamericana de la Salud Pública 1999; 6 (3).
26. Matthews, Stephen; Ribar, David; Wilhelm, Mark. The Effects of Economic Conditions and Access to Reproductive Health Services on State Abortion Rates and Birthrates. Family Planning Perspectives1997 March-April; 29: 52-60.

27. Morgan, Lynn M. Imagining the Unborn in the Ecuadorian Andes. Feminist Studies 1997 Summer; 23: 335+.

28. Muñoz Izquierdo, Carlos and Núñez Gornés, María de los Ángeles. Desarrollo de una Propuesta para la Construcción de Indicadores del Impacto Social de la Educación en América Latina y el Caribe. México, DF: Universidad Iberoamericano Press.http://www.prie.cl/espannol/seccion/ documento/ind_impact_soc.pdf. Accessed Jan 2003.

29. Oviedo Valdivieso, Nelson. Salud y derechos sexuales y reproductivos y reforma del sector salud. Correo Poblacional: Salud Reproductiva y Gerencia en Salud 2003 Sept; 11.

30. Pan-American Health Organization. PHO Home Page. www.paho.org. Accessed Feb 2004.

31. Pan-American Health Organization. Perfil de Salud de País: Ecuador, 1998-2001. http://www.paho.org/Spanish/ SHA/prflECU.htm. Accessed Nov. 2004.

32. Pan-American Health Organization. Violencia, un problema de salud pública que ya es pandemia. http://www.opsecu.org/ bevestre/revistas/violencia.pdf. Accessed 2004 Nov.

33. Remez, L. Both Contraceptive Use and Unplanned Births Are Common in Ecuador. International Family Planning Perspectives 1996 June; 22: 85-6.

34. Trakas, D.J. y Sanz E., eds. Childhood and medicine use in a cross-cultural perspective: A European concerted action. Luxembourg: European Commission, Directorate-General Science, Research and Development; 1996.

35. United Nations. Human Development Report 2003 website. www.un.org. Accessed Jan 252004.

36. United Nations Economic and Social Council. La Mujer en el año 2000: igualdad entre los géneros, desarrollo y paz para el siglo XXI: consecución de los objetivos estratégicos, adopción de medidas en las esferas de especial preocupación y medidas e iniciativas ulteriores: el papel de los hombres y los niños en el logro de la igualdad entre los géneros" 2004 March: 1-12.

37. United Nations Population Fund. Estado de la población mundial 2003. www.unfpa.org/upload/lib_pub_file/ 223_filename_swp2003_spa.pdf. Accessed Nov. 2004.

38. United Nations Population Fund. Proyectos y programas propuestos; Recomendación de la Directora Ejecutiva; Asistencia al Gobierno del Ecuador. New York: UNFPA; 2001 Jan 29-Feb 6.

39. United Nations Population Fund. The State of World Population 1997. www.unfpa.org/swp/1997/chapter1.htm. Accessed Nov 2004.

40. World Bank. World Bank Home Page. www.wb.org. Accessed Feb2004.

Jessica Beckwith received a B.A. in Economics from Grinnell College, Grinnell, Iowa, before spending a year in Ecuador as a Rotary Ambassadorial Scholar. She currently works as an Outreach Specialist in the National Marrow Donor Program's Office of Patient Advocacy, where she is responsible for identifying and addressing barriers facing patients who are considering an unrelated marrow or cord blood transplant. This is achieved through research and program development targeted to medically underserved populations and focusing on culturally competent care, health literacy, and health disparities. She hopes to begin an MPH program in policy and administration in the fall. 